\title{
Peningkatan Kualitas Pembelajaran IPA Melalui Pendekatan Inkuiri dengan Media Video Pada Peserta Didik Kelas III SDN 111/IX Desa Muhajirin
}

\author{
Ely Mawarni ${ }^{1}$ \\ ${ }^{1}$ Guru SDN 111/IX Desa Muhajirin Kabupaten Muaro Jambi, Indonesia \\ Correspondance email: elymawarni.111@gmail.com
}

\begin{abstract}
Abstrak. Permasalahan yang terjadi guru kurang menerapkan pembelajaran yang variatif dan kurang mengembangkan metode. Guru selalu memandang bahwa pembelajaran harus menghafal, selalu membaca buku, dan mengerjakan soal. Akibatnya peserta didik merasa jenuh, dan kurang antusias ditunjukkan dengan hasil belajar peserta didik yang rendah. Tujuan dari penelitian ini adalah meningkatkan kualitas pembelajaran IPA yang meliputi ketrampilan guru, aktivitas peserta didik, dan hasil belajar peserta didik pada peserta didik kelas III SDN 111/IX Desa Muhajirin. Rancangan penelitian ini adalah penelitian tindakan kelas dengan tahapan perencanaan, pelaksanaan tindakan (penerapan pendekatan inkuiri dengan media video), observasi dan refleksi. Penelitian ini dilaksanakan 2 siklus yang masing-masing siklus terdiri dari 2 pertemuan dan dilaksanakan 4 tahap. Penelitian ini dilaksanakan di SDN 111/IX Desa Muhajirin, dengan subjek penelitian ini adalah guru (peneliti) dan 34 peserta didik. Dalam pengumpulan data teknik yang digunakan menggunakan tes, observasi, dan dokumentasi. Teknik analisis data yang digunakan adalah dengan menggunakan data kuantitatif dan kualitatif. Hasil penelitian ini: (1) Ketrampilan guru pada siklus I diperoleh total skor 13 dengan kategori cukup, dan pada siklus II perolehan skor meningkat menjadi 29 dengan kategori sangat baik. (2) Aktivitas peserta didik pada siklus I rata-rata perolehan skor aktivitas peserta didik adalah 22,3 dengan kategori baik, pada siklus II rata-rata perolehan skor aktivitas peserta didik meningkat menjadi 28,5 dengan kategori sangat baik. (3) Hasil belajar peserta didik pada siklus I ketuntasan klasikal mencapai 59\% (20 dari 34 peserta didik) dengan nilai rata-rata kelas adalah 72,27 dan pada siklus II meningkat menjadi 88\% (30 dari 34 peserta didik) dengan nilai rata-rata 84,23. Penggunaan pendekatan inkuiri menggunakan media video pada pembelajaran IPA dapat meningkatkan ketrampilan guru, aktivitas peserta didik, dan hasil belajar pada peserta didik kelas III SDN 111/IX Desa Muhajirin. Pendekatan inkuiri menggunakan media video meningkatkan kualitas pembelajaran sehingga disarankan dapat diterapkan pada pelejaran lain.
\end{abstract}

Kata Kunci : Pendekatan inkuiri, media video, kualitas pembelajaran IPA

Abstract. The problems that occur teachers do not apply varied learning and less developed methods. The teacher always views that learning must memorize, always read books, and work on problems. As a result, students feel bored, and less enthusiastic, shown by low student learning outcomes. The purpose of this study was to improve the quality of science learning which includes teacher skills, student activities, and student learning outcomes in grade III students of SDN 111 / IX Muhajirin Village. The design of this research is classroom action research with the stages of planning, implementing the action (applying the inquiry approach with video media), observing and reflecting. This research was conducted in 2 cycles, each cycle consisting of 2 meetings and carried out in 4 stages. This research was conducted at SDN 111 / IX Muhajirin Village, with the subject of this study being the teacher (researcher) and 34 students. In data collection, the techniques used are tests, observation, and documentation. The data analysis technique used was quantitative and qualitative data. The results of this study: (1) The teacher's skills in the first cycle obtained a total score of 13 in the sufficient category, and in the second cycle the score increased to 29 in the very good category. (2) The activity of students in the first cycle the average score for the activity of students was 22.3 in the good category, in the second cycle the average score for the activity of students increased to 28.5 in the very good category. (3) The learning outcomes of students in cycle I classical completeness reached $59 \%$ (20 of 34 students) with an average class score of 72.27 and in cycle II increased to $88 \%$ (30 of 34 students) with an average grade -averaged 84.23. The use of an inquiry approach using video media in science learning can improve teacher skills, student activities, and learning outcomes in class III students of SDN 111 / IX Muhajirin Village. The inquiry approach using video media improves the quality of learning so it is suggested that it can be applied to other learning.

Keywords: Inquiry approach, video media, quality of science learning

\section{PENDAHULUAN}

IPA berhubungan dengan cara mencari tahu tentang alam secara sistematis dan bukan hanya kumpulan pengetahuan berupa fakta-fakta, konsep-konsep, prinsip-prinsip saja tetapi juga suatu proses penemuan. Pembelajaran IPA sangat berperan dalam proses pendidikan dan perkembangan teknologi karena memiliki upaya membangkitkan 
minat, mengembangkan IPTEK, dan pemahaman alam semesta yang mempunyai banyak fakta rahasia. Mata Pelajaran IPA di Sekolah Dasar bertujuan agar peserta didik memiliki kemampuan sebagai berikut : (1) Memperoleh keyakinan terhadap kebesaran Tuhan Yang Maha Esa berdasarkan keberadaan, keindahan, dan keteraturan alam ciptaan-Nya. (2) Pemahaman konsep-konsep IPA yang bermanfaat mengembangkan pengetahuan dan dapat diterapkan dalam kehidupan sehari-hari. (3) Mengembangkan rasa ingin tahu, sikap positif, dan kesadaran tentang adanya hubungan yang saling mempengaruhi antara IPA, lingkungan, teknologi, dan masyarakat. (4) Untuk menyelidiki alam sekitar, memecahkan masalah, dan membuat keputusan perlu Mengembangkan keterampilan proses (5) Meningkatkan kesa-daran untuk berperan serta dalam memelihara, menjaga, dan melestarikan ling-kungan alam. (6) Untuk menghargai alam dan segala keteraturannya sebagai salah satu ciptaan Tuhan. Perlu meningkatkan kesadaran (7) Memperoleh bekal penge-tahuan, konsep, dan keterampilan IPA sebagai dasar untuk melanjutkan pendi-dikan ke SMP/MTs dari Lampiran Peraturan Menteri Pendidikan Nasional Nomor 22 (2006:147).

Melihat permasalahan pembelajaran IPA dikelas III maka perlu adanya perbaikan dan peningkatan kualitas pembelajaran IPA dengan menerapkan model inovatif sehingga guru lebih kreatif, peserta didik konsentrasi, serta hasil belajar meningkat. Oleh karena itu peneliti bersama tim kolaborator berinisiatif menerapkan alternatif tindakan dengan dengan memilih metode pembelajaran inkuiri dengan media video. Dengan pendekatan inkuiri ini peserta didik diminta menyaksikan tayangan video sehingga dalam pembelajaran peserta didik tidak merasa bosan, lebih menguasai materi, dan meningkatkan hasil belajar.

Strategi inkuiri berarti suatu rangkaian kegiatan belajar yang melibatkan secara maksimal seluruh kemampuan peserta didik untuk mencari dan menyelidiki secara sistematis, kritis, logis, analitis, sehingga mereka dapat merumuskan sendiri penemuan dengan penuh percaya diri. Sasaran utama kegiatan inkuiri adalah (1) keterlibatan peserta didik secara maksimal dalam proses kegiatan belajar; (2) keterarahan kegiatan secara logis dan sistematis pada tujuan pembelajaran; (3) mengem-bangkan sikap percaya pada diri peserta didik tentang apa yang ditemukan dalam proses inkuiri (Gulo dalam Trianto, 2007).

Pembelajaran menggunakan video merupakan media pengajaran sangat menarik dan paling praktis penyajiannya dengan memanfaatkan komputer atau televisi. Video pembelajaran ini bersifat interaktif tutorial, yang mampu membimbing peserta didik untuk memahami sebuah materi melalui aspek audio visual saja, tidak multimedia secara penuh (Dina Indriana, 2011). Dari ulasan latar belakang tersebut maka peneliti mengkaji melalui penlitian tindakan kelas tentang "Peningkatan Kualitas Pembelajaran IPA Melalui Pendekatan Inkuiri dengan Media Video Pada Peserta Didik Kelas III SDN 111/IX Desa Muhajirin”.

\section{LANDASAN TEORI}

\section{Pengertian Belajar}

Dalam kehidupannya manusia mengalami proses belajar. Belajar merupakan perubahan perilaku bersifat permanen sebagai hasil dari pengalaman Morgan dalam Suprijono (2010:3). Terdapat tiga unsur utama tentang konsep belajar yaitu: a) belajar berkaitan dengan perubahan perilaku, b) perubahan perilaku terjadi karena proses pengalaman, dan c) perubahan perilaku bersifat permanen (Rifa'i dan Catharina, 2010). Menurut Hamalik (2010), belajar adalah suatu proses, suatu kegiatan dan bukan sutau hasil atau tujuan. Belajar efektif dapat membantu peserta didik untuk meningkatkan kemampuan yang diharapkan sesuai instruksional yang ingin dicapai. Untuk meningkatkan prestasi belajar peserta didik, guru memperhatikan kondisi internal dan eksternal peserta didik. Kondisi internal peserta didik adalah kondisi atau situasi yang ada dalam diri peserta didik, seperti kesehatan, keterampilan, kemampuan dan sebagainya. Kondisi eksternal adalah kondisi yang ada di luar diri pibadi peserta didik, misalnya ruang belajar bersih, sarana dan prasarana belajar memadai.

\section{Aktivitas Belajar}

Aktivitas belajar tidak hanya terjadi di dalam kegiatan intern belajar mengajar, tetapi juga terjadi di luar kegiatan tersebut. Aktivitas belajar peserta didik bisa diamati ketika proses kegiatan belajar mengajar dilaksanakan. Untuk membangkitkan keaktifan peserta didik, guru perlu mengajukan pertanyan dan membimbing diskusi peserta didik untuk memberikan tugas memecahkan masalah, menganalisis, mengambil keputusan dengan menyelenggarakan berbagai percobaan untuk menyimpulkan keterangan dan memberikan pendapat. Keaktifan peserta didik dalam proses pembelajaran akan menyebabkan interaksi tinggi antara guru, peserta didik ataupun peserta didik itu sendiri. Hal ini akan mengakibatkan suasana kelas menjadi segar dan kondusif, dimana masing - masing peserta didik dapat 
melibatkan kemampuannya semaksimal mungkin. Aktivitas yang timbul dari peserta didik mengakibatkan pula terbentuknya pengetahuan, keterampilan akan mengarah pada peningkatan prestasi dan hasil belajar peserta didik.

Dari beberapa pendapat disimpulkan bahwa hasil belajar merupakan perubahan perilaku individu meliputi aspek kognitif, afektif, dan psikomotorik sebagai hasil interaksi lingkungan setelah mengalami kegiatan belajar. Peneliti membatasi masalah pada ranah kognitif karena dapat diukur melalui evaluasi. Sehingga pada penelitian ini, peneliti akan mengolah data yang berupa nilai dari tes yang diberikan kepada peserta didik yang akan menentukan tingkat kelulusan belajar peserta didik pada pembelajaran IPA dengan nilai mencapai batas minimal KKM yaitu 70 .

\section{Pembelajaran Inkuiri}

Kondisi umum yang merupakan syarat timbulnya kegiatan inkuiri bagi peserta didik adalah (1) aspek sosial di kelas dan susasana terbuka yang mengundang peserta didik berdiskusi; (2) inkuiri berfokus pada hipotesis; (3) penggunaan fakta sebagai evidensi (informasi dan fakta). Dalam pembelajaran inkuiri guru mempunyai tugas yaitu sebagai berikut:

1. Motivator, memberi rangsangan agar peserta didik aktif dan bergairah berfikir.

2. Fasilitator, menunjukkan jalan keluar jika peserta didik mengalami kesulitan.

3. Penanya, menyadarkan peserta didik dari kekeliruan yang mereka buat.

4. Administrator, bertanggung jawab terhadap seluruh kegiatan kelas.

5. Pengarah, memimpin kegiatan siswa untuk mencapai tujuan yang diharapkan.

6. Manajer, mengelola sumber belajar, waktu, dan organisasi kelas.

7. Rewarder, memberi penghargaan pada prestasi yang dicapai peserta didik.

Kegiatan inkuiri dirancang untuk mengajak peserta didik secara langsung kedalam proses ilmiah kedalam waktu yang relatif singkat. Inkuiri dapat meningkatkan pemahaman sains, produktif dalam berfikir kreatif, dan peserta didik menjadi terampil dalam memperoleh dan menganalisis data.

\section{METODE PENELITIAN}

Rancangan dalam penelitian ini menggunakan Penelitian Tindakan Kelas (PTK) yang didefinisikan sebagai bentuk kajian yang bersifat reflektif dan situasional oleh pelaku tindakan yang dilakukan secara sitematis, terencana guna meningkatkan kualitas pembelajaran (Muslich 2010:9). Dengan demikian, tujuan penelitian adalah untuk memperbaiki kualitas pembelajaran IPA meliputi keterampilan guru, aktivitas peserta didik, dan hasil belajar pada peserta didik kelas III SDN 111/IX Desa Muhajirin. Metode PTK dilakukan dalam penelitian ini dengan alasan untuk memecahkan berbagai persoalan pembelajaran dengan melakukan berbagai tindakan alternatif. Selain itu, PTK dapat meningkatkan prestasi belajar, pengembangan keahlian mengajar, dan pengembangan sekolah. Dengan menggunakan metode PTK dapat memudahkan peneliti untuk mengetahui Peningkatan Kualitas Pembelajaran IPA Melalui Pendekatan Inkuiri dengan Media Video Pada Peserta Didik Kelas III SDN 111/IX Desa Muhajirin.

Dalam melaksanakan sebuah penelitian, PTK juga memiliki prosedur atau aturan yang perlu diperhatikan. Prosedur tersebut berguna bagi para guru yang akan melaksanakan PTK. Arikunto (2012, hlm. 16) menjelaskan bahwa secara garis besar terdapat empat tahapan yaitu: (1) perencanaan, (2) pelaksanaan, (3) pengamatan dan (4) refleksi. PTK bukan hanya bertujuan mengungkapkan penyebab dari berbagai permasalahan pembelajaran yang dihadapi seperti kesulitan siswa mempelajari pokok pembahasan tertentu, tetapi lebih penting lagi adalah memberikan pemecahan masalah berupa tindakan tertentu untuk meningkatkan kualitas proses dan hasil belajar.

\section{HASIL DAN PEMBAHASAN}

Subjek penelitian ini adalah guru (peneliti) dan siswa kelas III SDN 111/IX Desa Muhajirin terdiri dari 15 peserta didik laki-laki dan 19 peserta didik perempuan, jumlah keseluruhan adalah 34 peserta didik. Hasil penelitian ini didasarkan pada temuan hasil obeservasi aktivitas peserta didik, keterampilan guru dan hasil belajar disetiap siklusnya.

\section{Data Pelaksanaan Tindakan Siklus 1}

\section{Keterampilan Guru}

Hasil observasi keterampilan guru siklus I dapat dilihat pada tabel di bawah ini:

Tabel 1

Hasil Observasi Ketrampilan Guru Siklus I

\begin{tabular}{lrccc}
\hline No & Indikator yang diamati & \multicolumn{2}{c}{ Perolehan Skor } & Skor Rata-Rata \\
& & $\begin{array}{c}\text { Pertemuan } \\
\text { I }\end{array}$ & $\begin{array}{c}\text { Pertemuan } \\
\text { II }\end{array}$ & \begin{tabular}{c} 
Siklus 1 \\
\hline $\mathbf{1}$
\end{tabular} \\
\cline { 3 - 4 } & Mempersiapkan pra pembelajaran & 3 & 3 & 3 \\
\hline
\end{tabular}




\begin{tabular}{llllc}
$\mathbf{2}$ & Melaksanakan kegiatan awal & 3 & 3 & 3 \\
$\mathbf{3}$ & $\begin{array}{l}\text { Menayangkan video pembelajaran } \\
\mathbf{4}\end{array}$ & 3 & 3 & 3 \\
& $\begin{array}{l}\text { Membimbing peserta didik } \\
\text { mengidentifikasi masalah }\end{array}$ & 2 & 3 & 2,5 \\
$\mathbf{5}$ & $\begin{array}{l}\text { Membimbing peserta didik dalam } \\
\text { kelompok belajar }\end{array}$ & 2 & 3 & 2,5 \\
$\mathbf{6}$ & $\begin{array}{l}\text { Membimbing peserta didik dalam } \\
\text { menyampaikan diskusi }\end{array}$ & 2 & 2 & 2 \\
$\mathbf{7}$ & Membimbing membuat kesimpulan & 2 & 3 & 2,5 \\
$\mathbf{8}$ & Mengevaluasi & 3 & 2,5 \\
\hline$\quad$ Jumlah Skor & & & baik \\
\hline & Kategori
\end{tabular}

Dari hasil observasi keterampilan guru dalam mengelola pembelajaran dengan menggunakan pendekatan inkuiri dengan media video menyebutkan jumlah skor siklus I dari pertemuan I dan pertemuan II adalah sebesar 21. Dari data tersebut dapat disimpulkan bahwa keterampilan guru dalam proses pembelajaran pada siklus I masuk dalam kategori baik/B.

Keterampilan guru mempersiapkan pra pembelajaran diketahui skor rata-rata yang diperoleh guru dari pertemuan I dan pertemuan II adalah sebesar 3. Hasil ini masuk dalam kategori baik/B. Artinya, dalam kegiatan mempersiapkan pra pembelajaran, guru telah mempersiapkan alat, sumber, dan media pembelajaran.Untuk keterampilan melaksanakan kegiatan awal skor rata-rata pada pertemuan I dan pertemuan II yang diperoleh guru sebesar 3. Hasil ini masuk dalam kategori baik/B. Dalam melaksanakan kegiatan awal guru sudah melaksanakan apresiasi berupa pertanyaan "bagaimanakah bentuk permukaan bumi yang kita tinggali? Rata atau tidak? Mengapa?". Guru juga memberi motifasi dengan menyanyikan lagu naik-naik ke puncak gunung. Dalam kegiatan membimbing peserta didik dalam kelompok belajar mendapat skor rata-rata pada pertemuan I dan pertemuan II sebesar 2,5. Hasil ini termasuk dalam kategori baik/B. Guru telah membimbing peserta didik dalam kelompok belajar secara relevan dengan permasalahan. Pada kegiatan membimbing peserta didik dalam menyampaikan diskusi perolehan skor ratarata pada pertemuan I dan pertemuan II adalah sebesar 2,0 termasuk dalam kategori cukup/C. Pada kegiatan ini guru hanya satu kelompok saja yang dibimbing ketika menyampaikan diskusi.

Membimbing membuat kesimpulan diperoleh skor rata-rata 2,5. Hasil ini termasuk dalam kategori baik/B. Guru telah melakukan bimbingan kepada peserta didik dalam membuat kesimpulan secara sederhana. Dalam kegiatan evaluasi diperoleh skor rata-rata 2,5. Hasil ini termasuk dalam kategori baik/B. Pada kegiatan ini guru melaksanakan evaluasi tetapi tidak langsung dikoreksi.

\section{Aktivitas Siswa}

Hasil observasi aktivitas peserta didik siklus I dapat dilihat pada tabel berikut.

Tabel 2

Hasil Observasi Aktivitas Peserta didik Siklus I

\begin{tabular}{llccc}
\hline No & Indikator yang diamati & \multicolumn{2}{c}{ Perolehan Skor } & \multicolumn{2}{c}{$\begin{array}{c}\text { Skor Rata-Rata } \\
\text { Siklus 1 }\end{array}$} \\
\cline { 2 - 4 } & $\begin{array}{l}\text { Pertemuan I } \\
\text { Kesiapan peserta didik dalam }\end{array}$ & 2,8 & 2,8 & 2,8 \\
2 & $\begin{array}{l}\text { proses pembelajaran II } \\
\text { Peserta didik menyimak } \\
\text { penjelasan guru tentang tujuan } \\
\text { dan motivasi dalam belajar. }\end{array}$ & 2,4 & 2,8 & \\
3 & $\begin{array}{l}\text { Peserta didik menonton video } \\
\text { pembelajaran. }\end{array}$ & 2,6 & 2,6 & 2,8 \\
4 & $\begin{array}{l}\text { Peserta didik melakukan } \\
\text { pembagian tugas kelompok. }\end{array}$ & 3 & 3 & 2,6 \\
5 & $\begin{array}{l}\text { Peserta didik melaksanakan } \\
2\end{array}$ & 2,8 & 3 & 3 \\
\hline
\end{tabular}




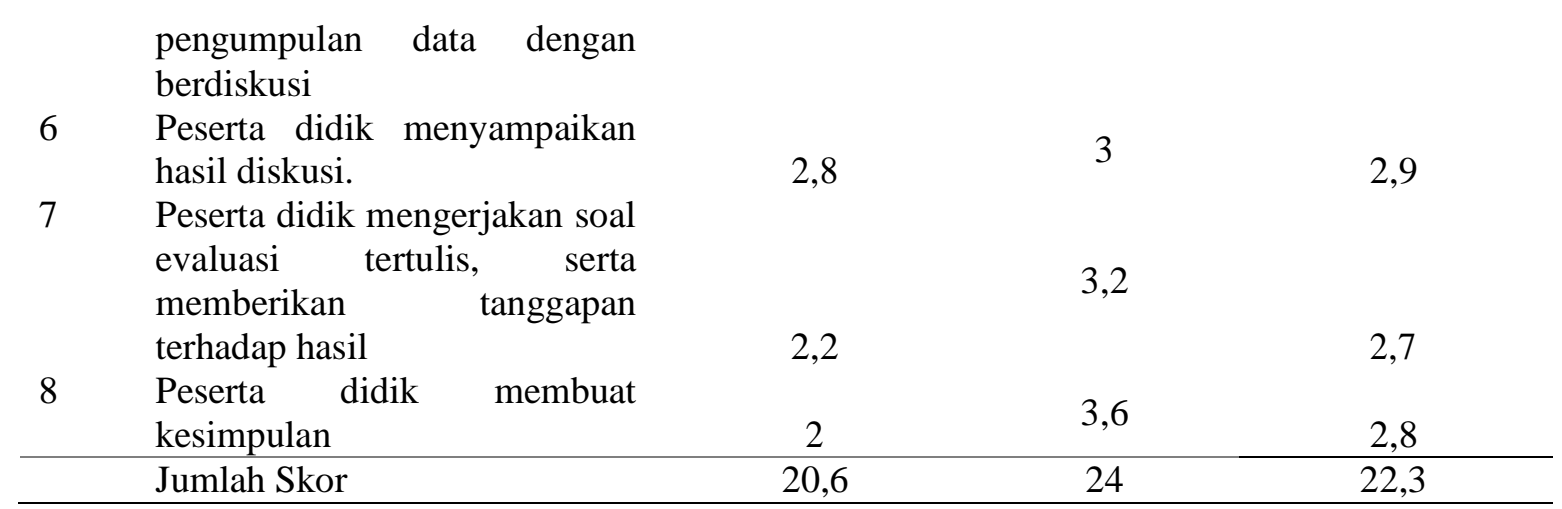

Berdasarkan hasil observasi aktivitas siswa pada siklus I yang tertera pada tabel dan grafik di atas dapat dijelaskan bahwa pembelajaran IPA melalui pendekatan inkuiri menggunakan media video diperoleh skor rata-rata dari pertemuan I dan pertemuan II pada siklus I adalah 22,3. Hasil ini termasuk dalam kategori baik/B. Namun ada beberapa aktivitas peserta didik yang kurang maksimal dikarenakan peserta didik belum pernah terlibat dalam proses pembelajaran dengan pendekatan inkuiri menggu-nakan media video. Peserta didik harus belajar aktif dan mandiri dengan berdiskusi memahami materi pembelajaran.

Indikator aktivitas peserta didik yang pertama adalah kesiapan peserta didik dalam proses pembelajaran diketahui skor rata-rata dari dua pertemuan adalah 2,8. Hasil ini termasuk dalam kategori baik/B. Berdasarkan hasil observasi diketahui bahwa sebagian besar peserta didik telah membawa alat belajar lengkap dan hanya beberapa peserta didik saja yang kurang mempersiapkan.

Aktivitas peserta didik selanjutnya adalah peserta didik menyimak penjelasan guru tentang tujuan dan motivasi dalam belajar. Pada indikator ini diketahui skor rata-rata dari pertemuan I dan pertemuan II adalah 2,6. Hasil ini termasuk dalam kategori baik/B. Dari data hasil observasi aktivitas peserta didik pada indikator ini disimpulkan masih ada sebagian kecil peserta didik menyimak penjelasan tentang tujuan dan motivasi dari guru namun sambil bergurau, namun sebagian besar siswa menyimak penjelasan materi dari guru dengan tenang.

Hasil obsevasi pada indikator siswa menonton video pembelajaran dari pengamatan yang dilakukan skor ratarata yang didapat pada pertemuan I dan pertemuan II adalah 2,6. Hasil ini termasuk dalam kategori baik/B. Karena ada beberapa anak yang menonton video sambil bercerita dengan teman.

Aktivitas peserta didik mengerjakan soal evaluasi tertulis mendapat nilai skor rata-rata pada pertemuan I dan pertemuan II sebesar 2,7. Hasil ini masuk dalam kategori baik/B. Berdasarkan hasil observasi diketahui sebagian besar peserta didik mengerjakan soal evaluasi tertulis dengan bantuan teman.

\section{Hasil Belajar}

Paparan hasil evaluasi tertulis pre tes yang dilakukan sebelum tindakan sebagai nilai awal siklus diperoleh data sebagai berikut:

Tabel 3

Paparan Hasil Evaluasi Tertulis Pre Tes

\begin{tabular}{ccccc}
\hline No & Rentang Nilai & Frekuensi Peserta Didik & Frekuensi Relatif & Kriteria \\
\hline 1 & $90-100$ & 0 & $0 \%$ & Tuntas \\
2 & $80-89$ & 1 & $3 \%$ & Tuntas \\
3 & $70-79$ & 4 & $12 \%$ & Tuntas \\
4 & $60-69$ & 8 & $24 \%$ & Belum Tuntas \\
5 & $50-59$ & 10 & $29 \%$ & Belum Tuntas \\
6 & $40-49$ & 7 & $21 \%$ & Belum tuntas \\
7 & $30-39$ & 4 & $12 \%$ & Belum Tuntas \\
\hline & Jumlah & 34 & $100 \%$ & \\
\hline
\end{tabular}

Pada tabel di atas menunjukkan bahwa terdapat nilai tertinggi 100 dan nilai terendah 30 . Terdapat $15 \%$ yaitu 5 dari 34 peserta didik tuntas belajar dan $85 \%$ yaitu 29 peserta didik dari 34 peserta didik belum tuntas belajar. 
Kriteria Ketuntasan Minimum (KKM) yang ditetapkan adalah sebesar 70. Perolehan rata-rata nilai pre tes peserta didik adalah sebesar 53,80.

Berdasarkan hasil evaluasi tertulis pembelajaran IPA melalui pendekatan inkuiri menggunakan media video pada akhir siklus I diperoleh data sebagai berikut:

\section{Tabel 4}

\section{Paparan Hasil Evaluasi Tertulis Siklus I}

\begin{tabular}{ccccc}
\hline No & Rentang Nilai & Frekuensi Peserta Didik & Frekuensi Relatif & Kriteria \\
\hline 1 & $90-100$ & 3 & $9 \%$ & Tuntas \\
2 & $80-89$ & 6 & 184 & Tuntas \\
3 & $70-79$ & 11 & $32 \%$ & Tuntas \\
4 & $60-69$ & 7 & $21 \%$ & Belum Tuntas \\
5 & $50-59$ & 4 & $12 \%$ & Belum Tuntas \\
6 & $40-49$ & 3 & $9 \%$ & Belum tuntas \\
7 & $30-39$ & 0 & $0 \%$ & Belum Tuntas \\
\hline & Jumlah & 17 & 34 & $100 \%$ \\
\hline
\end{tabular}

Pada tabel menunjukkan bahwa hasil belajar IPA diperoleh data nilai tertinggi adalah 100, nilai terendah adalah 40, rata-rata hasil belajar adalah 72,27. Persentase ketuntasan hasil belajar adalah $58 \%$, (20 dari 34 peserta didik) dengan $\mathrm{KKM} \geq 70$, sedangkan 42\% (14 dari 34 peserta didik) dalam kualifikasi belum tuntas.

\section{Data Pelaksanaan Tindakan Siklus II}

\section{Keterampilan Guru}

Hasil observasi keterampilan guru siklus II dapat dilihat pada tabel di bawah ini:

Tabel 5

\section{Hasil Observasi Keterampilan Guru Siklus II}

\begin{tabular}{|c|c|c|c|c|}
\hline \multirow[t]{2}{*}{ No } & \multirow[t]{2}{*}{ Indicator yang diamati } & \multicolumn{2}{|c|}{ Perolehan Skor } & \multirow{2}{*}{$\begin{array}{c}\text { Skor Rata- } \\
\text { Rata } \\
\text { Siklus } 1\end{array}$} \\
\hline & & Pertemuan I & Pertemuan II & \\
\hline \multicolumn{5}{|l|}{$\mathbf{1}$} \\
\hline & Mempersiapkan pra pembelajaran & 4 & 4 & 4 \\
\hline 2 & Melaksanakan kegiatan awal & 3 & 4 & 3,5 \\
\hline 3 & Menayangkan video pembelajaran & 4 & 4 & 4 \\
\hline 4 & Membimbing peserta didik mengidentifikasi masalah & 3 & 4 & 4 \\
\hline 5 & & & 3 & \\
\hline & Membimbing peserta didik dalam kelompok belajar & 3 & & 3,5 \\
\hline 6 & $\begin{array}{l}\text { Membimbing peserta didik dalam menyampaikan } \\
\text { diskusi }\end{array}$ & 3 & 4 & 3 \\
\hline 7 & Membimbing membuat kesimpulan & 3 & 4 & 3,5 \\
\hline 8 & Mengevaluasi & 4 & 4 & 3,5 \\
\hline \multicolumn{2}{|r|}{ Jumlah skor } & & & 29 \\
\hline \multicolumn{2}{|r|}{ kategori } & & & Sangat baik \\
\hline
\end{tabular}

2. Aktivitas Siswa

Hasil observasi aktivitas peserta didik siklus II dapat dilihat pada tabel di bawah ini.

Tabel 6

Hasil Observasi Aktivitas Peserta didik Siklus II

\begin{tabular}{|c|c|c|c|c|}
\hline \multirow[t]{2}{*}{ No } & \multirow[t]{2}{*}{ Indikator yang diamati } & \multicolumn{2}{|c|}{ Perolehan Skor } & \multirow{2}{*}{$\begin{array}{c}\text { Skor Rata-Rata } \\
\text { Siklus } 1 \\
\end{array}$} \\
\hline & & Pertemuan I & Pertemuan II & \\
\hline 1 & Kesiapan peserta didik dalam & 3,4 & 3,6 & 3,5 \\
\hline
\end{tabular}




\begin{tabular}{|c|c|c|c|c|}
\hline & proses pembelajaran & & & \\
\hline 2 & $\begin{array}{l}\text { Peserta didik menyimak } \\
\text { penjelasan guru tentang } \\
\text { tujuan dan motivasi dalam } \\
\text { belajar. }\end{array}$ & 3,8 & 3,2 & 3,5 \\
\hline 3 & $\begin{array}{l}\text { Peserta didik menonton video } \\
\text { pembelajaran. }\end{array}$ & 3,8 & 3,8 & 3,8 \\
\hline 4 & $\begin{array}{l}\text { Peserta didik melakukan } \\
\text { pembagian tugas kelompok. }\end{array}$ & 3,4 & 3,4 & 3,4 \\
\hline 5 & $\begin{array}{l}\text { Peserta didik melaksanakan } \\
\text { pengumpulan data dengan } \\
\text { berdiskusi }\end{array}$ & 3,8 & 3,6 & 3,7 \\
\hline 6 & $\begin{array}{l}\text { Peserta didik menyampaikan } \\
\text { hasil diskusi. }\end{array}$ & 3,8 & 3,2 & 3,5 \\
\hline 7 & $\begin{array}{l}\text { Peserta didik mengerjakan } \\
\text { soal evaluasi tertulis, serta } \\
\text { memberikan } \\
\text { terhadap hasil }\end{array}$ & 3,4 & 3,8 & 3,6 \\
\hline 8 & $\begin{array}{l}\text { Peserta didik } \\
\text { kesimpulan }\end{array}$ & 3,4 & 3,6 & 2,8 \\
\hline & Jumlah Skor & 28,6 & 28,2 & 28,5 \\
\hline
\end{tabular}

Berdasarkan hasil observasi aktivitas peserta didik pada siklus II yang tertera pada tabel dan grafik di atas dapat dijelaskan bahwa pembelajaran IPA melalui pendekatan inkuiri menggunakan media video diperoleh skor ratarata dari pertemuan I dan pertemuan II pada siklus II adalah 28,5. Hasil ini termasuk dalam kategori sangat baik/A. Aktivitas peserta didik sangat maksimal dikarenakan peserta didik terlibat dalam proses pembelajaran dengan pendekatan inkuiri menggunakan media video. Peserta didik belajar aktif dan mandiri dengan berdiskusi memahami materi pembelajaran.

Indikator aktivitas peserta didik yang pertama adalah kesiapan peserta didik dalam proses pembelajaran diketahui skor rata-rata dari dua pertemuan adalah 3,5. Hasil ini termasuk dalam kategori sangat baik/A. Berdasarkan hasil observasi diketahui bahwa sebagian besar peserta didik telah membawa alat belajar lengkap. Aktivitas peserta didik selanjutnya adalah peserta didik menyimak penjelasan guru tentang tujuan dan motivasi dalam belajar. Pada indikator ini diketahui skor rata-rata dari pertemuan I dan pertemuan II adalah 3,5. Hasil ini termasuk dalam kategori sangat baik/A. Dari data hasil observasi aktivitas peserta didik pada indikator ini disimpulkan sebagian besar peserta didik menyimak penjelasan materi dari guru dengan tenang.

Hasil obsevasi pada indikator peserta didik menonton video pembelajaran dari pengamatan yang dilakukan skor rata-rata yang didapat pada pertemuan I dan pertemuan II adalah 3,8. Hasil ini termasuk dalam kategori sangat baik/A. Karena hampir semua anak yang menonton video dengan tenang. Dalam indikator peserta didik melakukan pembagian tugas kelompok semua peserta didik dibentuk kelompok oleh guru sehingga kelompok yang terbentuk heterogen. Skor rata-rata dari pertemuan I dan pertemuan II adalah 3,4. Hasil ini termasuk dalam kategori sangat baik/A.

Indikator peserta didik melaksanakan pengumpulan data dengan berdiskusi mendapat skor rata- rata dari pertemuan I dan pertemuan II adalah 3,7 karena dari semua kelompok mengerjakan secara bersama-sama. Hasil ini termasuk dalam kategori sangat baik/A.Dari indikator peserta didik menyampaikan hasil diskusi mendapat skor ratarata dari pertemuan I dan pertemuan II adalah 3,5 karena semua perwakilan kelompok menyampaikan hasil diskusinya ke depan kelas. Hasil ini termasuk dalam kategori sangat baik/A. Aktivitas peserta didik mengerjakan soal evaluasi tertulis mendapat nilai skor rata-rata pada pertemuan I dan pertemuan II sebesar 3,5. Hasil ini masuk dalam kategori sangat baik/B. Berdasarkan hasil observasi diketahui sebagian besar peserta didik mengerjakan soal evaluasi tertulis dengan percaya diri tanpa bantuan teman.

\section{Hasil Belajar}

Evaluasi hasil belajar siswa pada pembelajaran IPA melalui pendekatan inkuiri menggunakan media video pada siklus II diperoleh data sebagai berikut: 
Tabel 7.

Distribusi Frekuensi Nilai Evaluasi Tertulis Siklus II

\begin{tabular}{lllll}
\hline No & Rentang Nilai & Frekuensi Nilai & Frekuensi Relatif & kategori \\
\hline 1 & $90-100$ & 9 & $26 \%$ & Tuntas \\
2 & $80-89$ & 11 & $32 \%$ & Tuntas \\
3 & $70-79$ & 10 & $29 \%$ & Tuntas \\
4 & $60-69$ & 4 & $12 \%$ & Belum tuntas \\
5 & $50-59$ & 0 & $0 \%$ & Belum tuntas \\
6 & $40-49$ & 0 & $0 \%$ & Belum tuntas \\
7 & $30-39$ & 0 & $0 \%$ & Belum tuntas \\
\hline & Jumlah & 34 & $100 \%$ & \\
\hline
\end{tabular}

Pada tabel hasil belajar individual pada evaluasi akhir siklus II di atas diperoleh data nilai tertinggi adalah 100, nilai terendah adalah 60, rata-rata hasil belajar adalah 84,23. Persentase ketuntasan hasil belajar adalah 88\% (30 dari 34 peserta didik) dengan $\mathrm{KKM} \geq 70$, sedangkan 12\% (4 dari 34 peserta didik) dalam kualifikasi belum tuntas. Adapun refleksinya adalah sebagai berikut:

1. Ketarampilan guru meningkat, pada siklus II terlihat guru telah memotivasi peserta didik untuk menggunakan media pembelajaran berupa magnet batang yang telah disediakan disetiap kelompok. Media tersebut membantu peserta didik memahami materi yang sedang dipelajari. Guru telah memberikan arahan tentang tugas kelompok dengan jelas. Guru juga membimbing kelompok berdiskusi membagi tugas secara rata kesetiap anggota. Selain itu guru telah berhasil mengajak peserta didik berpartisipasi aktif untuk berdiskusi dalam kegiatan kelompok.

2. Aktivitas pesert didik meningkat, nampak dari hasil observasi peserta didik telah antusias dalam kegiatan pembelajaran. Dalam menyelesaikan tugas kelompok siswa telah bekerjasama dan berdiskusi dengan anggota kelompok. Peserta didik juga telah berani menyampaikan pendapat dan berperan aktif dalam kelompok. Kegiatan kelompok tidak hanya didominasi peserta didik yang berkemampuan baik saja, namun seluruh peserta didik telah memberikan sumbangsih dalam menyelesaikan tugas kelompok secara bersama-sama. Selain itu peserta didik telah mengerjakan soal evaluasi secara individu.

3. Hasil belajar peserta didik pada siklus II diperoleh data $88 \%$ yaitu 30 dari 34 peserta didik tuntas belajar dan $12 \%$ yaitu 4 dari 30 peserta didik belum tuntas belajar. Sangat jelas terlihat sebaran nilai berkisar dari nilai terendah 50 dan nilai tertinggi 100. Adapun rata kelas hasil belajar yaitu 84,23. Hasil tersebut sudah memenuhi kriteria indikator keberhasilan yang ditentukan yaitu $75 \%$ peserta didik tuntas belajar dengan memenuhi $\mathrm{KKM} \geq 70$.

Berdasarkan hasil refleksi di atas dapat ditarik kesimpulan bahwa pembelajaran IPA melalui pendekatan inkuiri menggunakan media video pada siklus II sudah memenuhi kriteria indikator keberhasilan yaitu aktivitas peserta didik meningkat sekurang-kurangnya baik, aktivitas guru meningkat sekurangkurangnya baik, dan $88 \%$ peserta didik mengalami ketuntasan belajar dengan mencapai KKM $\geq 70$.

\section{SIMPULAN}

Modul mata pelajaran Pendidikan Pancasila dan Kewarganegaran untuk siswa SMK telah dikembangkan melalui langkah-langkah yaitu analisis kebutuhan awal, penyusunan desain, pembuatan produk, validasi ahli dan uji coba lapangan. Produk modul mata pelajaran PPKn menarik dan sesuai dengan karakteristik siswa, hal ini ditandai dengan hasil $81 \%$ modul berkualifikasi sangat baik, ditinjau dari adanya peta kedudukan modul, petunjuk penggunaan modul, teks pada modul, gambar yang terdapat pada modul, meningkatnya daya tarik belajar, daya belajar secara mandiri, penggunaan bahasa, relevansi materi dengan kondisi kekinian, sehingga modul mata pelajaran PPKn dapat dinyatakan menarik, sesuai dengan karakteristik siswa. Produk modul Mata Pelajaran PPKn dapat meningkatkan nilai siswa karena dengan menggunakan modul hasil dari nilai rata-rata yang diperoleh siswa yaitu 85 dibandingkan dengan tidak menggunakan modul, sehingga nilai mata pelajaran PKPn meningkat secara prosentase yakni nilai diatas Kriteria Ketuntasan Minimal yaitu 70. 
Ely Mawarni, Peningkatan Kualitas Pembelajaran IPA Melalui Pendekatan Inkuiri dengan Media Video Pada Peserta Didik Kelas III SDN 111/IX Desa Muhajirin

\section{DAFTAR PUSTAKA}

Borg,Walter R and Gall, Meridith. Damien 2003. Educational Research an Introduction. New York \& London: Longman

Eliyawati. Pengembangan Modul Kinematika Gerak Dengan Analisis Vektor Pada SMA Kelas XI. Tesis, Program Pascasarjana Universitas Lampung. Lampung. 2015.

Sudjana, Nana dan Rivai, Ahmad. 2007. Teknologi Pengajaran. Bandung: Sinar Baru Algensindo

Sugiono. 2009. Metode Penelitian Pendidikan Pendekatan kuantitatif, kualitatif dan R\&D. Bandung: ALFABETA.

Sukmadinata, S. N. 2008. Metode Penelitian Pendidikan. Bandung: PT.Remaja Rosdakarya.

Wena Made. 2010. Strategi Pembelajaran Inovatif Kontemporer. Jakarta: Bumi Aksara 